BMJ Open

Sport \&

Exercise

Medicine

\section{Effects of football sporting activity on renal and liver functions among young undergraduate students of a Nigerian tertiary institution}

To cite: Ekun $O A$, Emiabata AF, Abiodun OC, et al. Effects of football sporting activity on renal and liver functions among young undergraduate students of a Nigerian tertiary institution. BMJ Open Sport Exerc Med 2017;3:e000223.

doi:10.1136/bmjsem-2017000223

Received 12 January 2017 Revised 11 April 2017 Accepted 03 May 2017

\section{CrossMark}

\author{
${ }^{1}$ Department of Medical \\ Laboratory Science, College \\ of Medicine, University of \\ Lagos, Lagos, Nigeria \\ 2Department of Haematology \\ and Blood Transfusion, \\ College of Medicine, \\ University of Lagos, Lagos, \\ Nigeria \\ ${ }^{3}$ Laboratory Department, \\ General Hospital ljede, Lagos \\ State Health Service \\ Commission, Lagos, Nigeria
}

Correspondence to Dr Oloruntoba Ayodele Ekun; ayodele1619.oe@gmail.com, ayodele1619@yahoo.com

\section{ABSTRACT}

Background Football sporting exercise is one of the most popular events in the world. While there are welldocumented reports on the effects of different athletic sporting activities on the biochemical markers of renal and liver functions, there are paucity of welldocumented reports on the effects of football activity on Nigerian sportsmen, hence the need for this study. Method Biochemical markers of renal and liver functions (urea, creatinine, aspartate aminotransaminase (AST), alanine aminotransaminase (ALT), alkaline phosphatase (ALP)) were determined using Cobas c 111 auto-analyser by Roche.

Results The mean urea $(\mathrm{mmol} / \mathrm{L}) \pm \mathrm{SEM}$, creatinine $(\mu \mathrm{mol} / \mathrm{L}) \pm \mathrm{SEM}, \mathrm{AST}(\mathrm{U} / \mathrm{L}) \pm \mathrm{SEM}, \mathrm{ALT}(\mathrm{U} / \mathrm{L}) \pm \mathrm{SEM}$ and ALP (U/L) \pm SEM values before and after soccer exercise were $3.56 \pm 0.12,3.76 \pm 0.13, p=0.000 ; 79.36 \pm 1.53$, $95.90 \pm 2.03, p=0.000 ; 32.54 \pm 1.15,35.81 \pm 1.32$, $\mathrm{p}=0.000 ; 15.68 \pm 1.02,13.97 \pm 0.81, \mathrm{p}=0.000$; and $82.21 \pm 3.67,86.08 \pm 3.86, p=0.046$, respectively. Pearson's degree of association for AST and ALT before and after exercise were $r=0.678, p=0.000$ and $r=0.770, p=0.000$, respectively; ALT and ALP before exercise showed a positive and significant association $(r=0.317, p=0.028)$. On the other hand, there was a negative but insignificant correlation between urea before exercise and ALP after exercise $(r=-0.003$, $\mathrm{p}=0.982$ ) and urea before exercise versus AST after exercise $(r=-0.120, p=0.418)$. A positive but insignificant association was observed between urea and creatinine before exercise $(r=0.093, p=0.530)$. Conclusion Football sporting event is associated with an increase in urea, creatinine, AST and ALP plasma values, and such interpretation of these parameters among sportsmen should be done with caution.

\section{INTRODUCTION}

Physical exercise is a bodily activity that develops or maintains physical fitness and overall health. ${ }^{1}$ It is often practised to strengthen muscles and to optimise athletic skills. Exercise has multiple beneficial effects on the human body such as increasing threshold for pain, reducing high blood pressure and preventing obesity and heart disease. ${ }^{2-4}$ Regular exercise decreases the risk of certain cancers (prostate, lung, colon cancers) and improves cognitive functioning. ${ }^{3}$ It has been shown that exercise has a neuroprotective effect in many neurodegenerative and neuromuscular diseases. ${ }^{4-6}$ A previous study has also shown that exercise decreases anxiety and depression by increasing oxygen supply to the brain tissue and by increasing dopamine, serotonin, norepinephrine and acetylcholine. $^{3} \quad$ Exercise also promotes maximal hepatic glycogenolysis and gluconeogenesis by additive fall in insulin and rise in glucagon levels.

When challenged with any physical tasks, the human body responds through a series of integrated changes in function that involve most of its metabolically active organs (liver, kidney). The magnitude of these changes depends largely on the intensity and duration of the training sessions, force or load used in training and the body's initial level of fitness.

It is well established that deliberate or accidental trauma to tissues can lead to abnormal enzyme activity in the plasma. Physical exercise, however, when strenuous or prolonged, has been shown to affect enzyme activities. ${ }^{1}$ Several studies have examined the changes in serum enzyme concentrations after sports activities. In one of such studies, after ultra-long distance running, the activities of plasma aspartate aminotransaminase (AST) and alanine aminotransaminase (ALT) were found to be elevated up to fivefold and threefold, respectively. ${ }^{2}$ Ahmad $e t ~ a l^{7}$ investigated the effect of 8 weeks of endurance exercise activities on liver enzymes and observed that a long endurance activity results in a significant reduction in ALT and AST 
Table 1 Mean \pm SEM anthropometric data of the participants

\begin{tabular}{cllll}
\hline Demographic variables & Weight $(\mathbf{k g})$ & Height $\mathbf{( m )}$ & BMI $\mathbf{( k g / \mathbf { m } ^ { 2 } )}$ & Age (years) \\
\hline Mean & 67.35 & 1.69 & 23.75 & 24 \\
\pm & \pm & \pm & \pm & \pm \\
SEM & 1.41 & 0.02 & 0.60 & 4.23 \\
\hline
\end{tabular}

BMI, body mass index.

enzyme activities. However, in the study of Bijeh et al, ${ }^{8}$ AST and ALT levels after 8 weeks of swimming exercise were investigated among healthy women, and in that study, no significant changes were observed. While these findings seem encouraging, it is worthy of note that there are paucity of similar documented reports on men and women who engaged regularly on football sporting activity particularly among the Nigerian population, hence the need for this study.

Furthermore, it has been reported that after a moderate-intensity and high-intensity exercise, there is a decrease in urine volume and a marked reduction in renal plasma flow and renal filtration rate. ${ }^{56}$

A previous study had opined that athletes commonly display high resting urea concentrations, probably as a result of the continual stress of training. Urea concentrations are also generally increased after the performance of sports activity and may remain elevated for 24-40 hours after exercise. ${ }^{9}$ An increase in urea concentration may be related to a reduction in renal blood flow (and glomerular filtration rate) secondary to fluid volume deficiency, increased protein catabolism and/or bleeding into the intestine, all of which may occur after sports activity. Creatinine concentration (the product of creatine breakdown from skeletal muscle) also generally increases after sports activity. The increase in plasma creatinine concentration is probably the result of the release of creatinine from the working muscles, dehydration and/or a reduction in renal blood flow and glomerular filtration rate. The transient increase in creatinine and urea after strenuous exercise is thought to be of little clinical concern to renal function. However, some investigators have observed small but significant indices of renal damage after prolonged endurance exercise resulting from low blood flow to the kidney. ${ }^{10}$ Acute renal failure in some athletes after a sports event has been reported. ${ }^{11}$

It remains to be determined whether the repeated performance of prolonged endurance events leads to renal alterations that are of concern from a health point of view.

While there are robust documented reports on the effects of athletic sporting exercise (both endurance and brisk) on biochemical markers of liver and renal function, the same cannot be said about the effects of regular football sporting exercise on biochemical markers of liver and renal functions particularly among Nigerian sportsmen; hence, this study intends to evaluate changes in biochemical markers of renal and liver functions among young undergraduate men who play football on a regular basis.

\section{MATERIALS AND METHODS}

A cross-sectional study was carried out in apparently healthy young undergraduate male students of the College of Medicine of University of Lagos who have been participating in football activities at least three times a week for a period of 3 months.

An approval from the institutional ethics and research board of Lagos University Teaching Hospital was obtained (ADM/DCST/HREC/126). This study was in total conformity with the institution's ethics and research standards and with the Helsinki Declaration. Thus, informed consent of all the participants was obtained before the commencement of this study.

\section{SAMPLE SIZE}

For the purpose of this study, a convenient sampling method involving 48 participants was used. The participants' pre-exercise and post-exercise blood samples were taken. The pre-exercise blood samples collected served as control samples for this study. Five millilitres each of blood samples were collected before and after football exercise from each participant.

\section{PROCEDURE FOR DATA COLLECTION}

Data collection was by the use of self-administered questionnaire. The questionnaire included sociodemographic data as well as anthropometric data such as weight and height, and the questions were close ended.

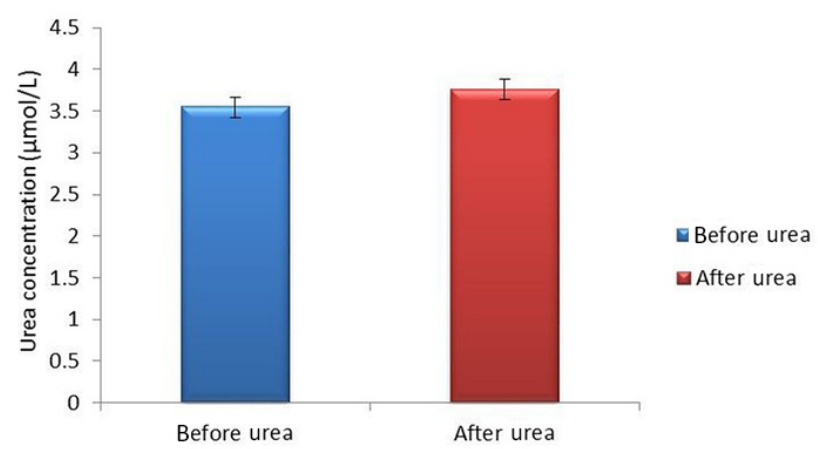

Figure 1 Mean urea $\pm S E M$ values in pre- and post-football exercise. 


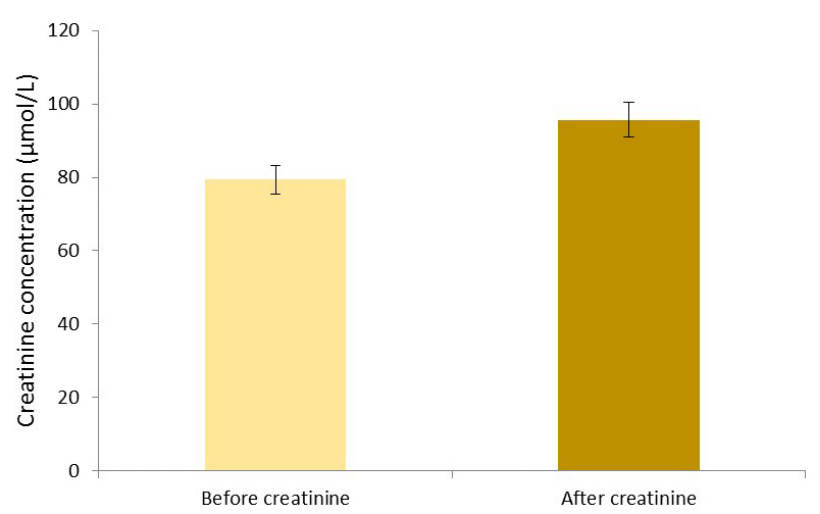

Figure 2 Mean creatinine \pm SEM values in pre- and postfootball exercise.

\section{SELECTION CRITERIA}

\section{Inclusion criteria}

Apparently healthy men who participate regularly in football sport activities for not less than a minimum of 3 months were considered for this study.

Participants were within age 18-30.

\section{Exclusion criteria}

This study excluded children and elderly individuals.

\section{EXERCISE PROTOCOL}

The football match consists of two halves, each half lasting for $45 \mathrm{~min}$ while the rest period at half time is $15 \mathrm{~min}$.

\section{BLOOD SAMPLING}

Blood sample was taken by venipuncture from the antecubital vein using a sterile pyrogen-free needle, and stasis was avoided during the process of blood collection. Blood samples were collected before football exercise and $30 \mathrm{~min}$ after football exercise from all the participants. The samples were dispensed into plain bottles and were allowed to clot at room temperature, after which the samples were centrifuged at the speed of $3000 \mathrm{rpm}$ for $5 \mathrm{~min}$. The serum was then obtained

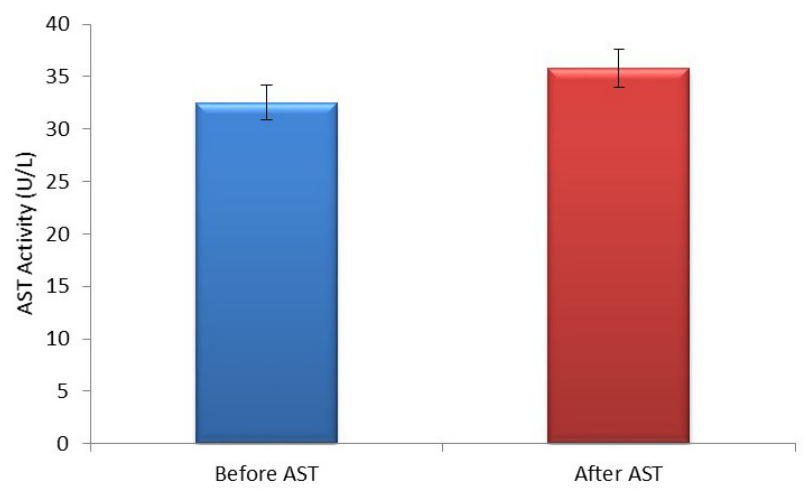

Figure 3 Mean \pm SEM AST activity in pre and post-football exercise. AST, aspartate aminotransaminase.

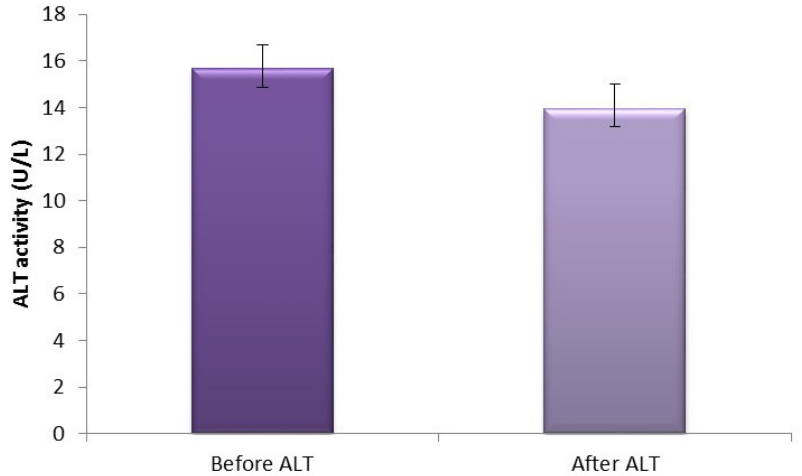

Figure 4 Mean \pm SEM of ALT activity in pre- and postfootball exercise. ALT, alanine aminotransferase.

from each sample and was evaluated for urea, creatinine, AST, ALT and alkaline phosphatase (ALP) levels.

\section{METHODOLOGY}

The urea, creatinine, ALT, AST and ALP were determined using Cobas c 111 auto-analyser by Roche.

\section{STATISTICAL ANALYSIS}

The data obtained from all the methods described above were analysed using SPSS software V.15. Dependent Student t-test was used to compare the groups. Pearson correlation coefficient determination was performed to evaluate the degree of association. Quantitative data were expressed as mean \pm SEM. Probability values of less than $0.05(\mathrm{p}<0.05)$ were considered to be statistically significant. Data are displayed in the form of tables and figures.

\section{DISCUSSION}

In this study, we evaluated liver and renal function biochemical markers among young undergraduate male footballers by determining their AST, ALT, ALP, urea and creatinine before and after football exercise. The mean anthropometric measurement of the participants was evaluated, and it was observed that the participants had a mean body mass index (BMI) value

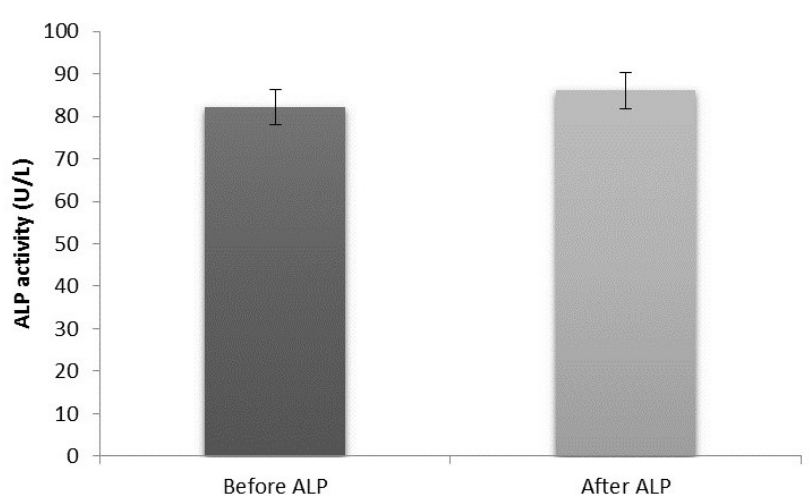

Figure 5 Mean \pm SEM of ALP activity in pre and postfootball exercise. ALP, alkaline phosphatase. 
Table 2 Degree of association of the renal profile parameters studied before and after exercise

\begin{tabular}{llllll}
\hline & $\begin{array}{l}\text { Urea before versus } \\
\text { creatinine before }\end{array}$ & $\begin{array}{l}\text { Urea after versus } \\
\text { creatinine before }\end{array}$ & $\begin{array}{l}\text { Urea before versus } \\
\text { creatinine after }\end{array}$ & $\begin{array}{l}\text { Urea before versus } \\
\text { creatinine after }\end{array}$ & $\begin{array}{l}\text { Urea before versus } \\
\text { creatinine after }\end{array}$ \\
\hline $\mathrm{r}$ & 0.093 & 0.154 & -0.004 & 0.941 & 0.745 \\
$\mathrm{p}$ Value & 0.530 & 0.297 & 0.979 & $0.000^{\star}$ & $0.000^{\star}$ \\
\hline
\end{tabular}

*Significant level at $\mathrm{p}<0.05$; before, before exercise; after, after exercise; $r$, Pearson correlation coefficient.

Table 3 Degree of association of liver function enzymes studied before and after exercise

\begin{tabular}{llllllll}
\hline & $\begin{array}{l}\text { AST before } \\
\text { versus ALT } \\
\text { before }\end{array}$ & $\begin{array}{l}\text { AST after } \\
\text { versus ALT } \\
\text { after }\end{array}$ & $\begin{array}{l}\text { AST before } \\
\text { versus ALP } \\
\text { before }\end{array}$ & $\begin{array}{l}\text { AST after } \\
\text { versus ALP } \\
\text { after }\end{array}$ & $\begin{array}{l}\text { AST before } \\
\text { versus AST } \\
\text { after }\end{array}$ & $\begin{array}{l}\text { ALT before } \\
\text { versus ALT } \\
\text { after }\end{array}$ & $\begin{array}{l}\text { ALP before } \\
\text { versus ALP } \\
\text { after }\end{array}$ \\
\hline $\mathrm{r}$ & 0.678 & 0.770 & 0.194 & 0.102 & 0.803 & 0.910 & 0.875 \\
$\mathrm{p}$ & $0.000^{*}$ & $0.000^{*}$ & 0.185 & 0.492 & $0.000^{*}$ & $0.000^{*}$ & $0.000^{*}$ \\
Value & & & & & & & \\
\hline
\end{tabular}

*Significant level at $\mathrm{p}<0.05$; before, before exercise; after, after exercise; $r$, Pearson correlation coefficient.

that was within the acceptable physiological range limit (table 1), thus ruling out overweight and obesity among the participants.

Effects of football exercise activity on renal function biochemical marker parameters

There was a significant increase $(\mathrm{p}<0.05)$ in renal function biochemical parameters studied (urea and creatinine) after football exercise when compared with the pre-exercise values (figures 1 and 2, respectively). This observation agrees with the previous studies of Jacobs et $a l^{5}$ and Weinberger et $a l^{6}$ where it was reported that after a moderate-intensity and highintensity exercise, there is a decrease in urine volume and a marked reduction in renal plasma flow and filtration rate leading to the increase in urea and creatinine values observed after exercise. Since football exercise can be regarded as a moderate-intensity to high-intensity exercise, it is possible that there was probably a decreased urine volume as a result of marked reduction in renal plasma flow as well as reduction in glomerular filtration rate during football activities, hence an increase in post-football exercise urea and creatinine values. Furthermore, a study by Welsh et $a l^{9}$ opined that urea elevation remains for 24-40 hours after exercise; this is because of reduced renal blood flow and glomerular filtration rate. However, this finding is secondary to fluid volume deficiency, increased protein catabolism and/or bleeding into the intestine. All these are seen in sports activities.

\section{Football exercise and liver enzyme activities}

Moreover, we observed a significant $(\mathrm{p}<0.05)$ increase in the liver enzyme AST and ALP while a significant decrease $(\mathrm{p}<0.05)$ was observed in ALT activities after football exercise (figures 3,4 and 5, respectively). The findings from this study agreed partly with the previous study of Kawano et $a l^{2}$ where AST and ALT were found to be elevated up to fivefold and threefold, respectively, in ultra-long distance runners. The slight difference in this observation could be a result of different types of sporting activity involved and the duration of this activity. Our findings also agreed with those of Burger-Mendonca et $a l^{12}$ who studied Brazilian triathletes after a half Ironman competition and observed a significant increase in AST and ALP levels after competition whereas the ALT value showed no significant change. Also, this study agrees with another study by Yazgaldi et $a l^{13}$ who

Table 4 Degree of association of the renal function and liver function parameters before and after exercise

\begin{tabular}{|c|c|c|c|c|c|c|}
\hline & $\begin{array}{l}\text { Urea before } \\
\text { versus AST } \\
\text { before }\end{array}$ & $\begin{array}{l}\text { Urea before } \\
\text { versus ALT } \\
\text { before }\end{array}$ & $\begin{array}{l}\text { Urea before } \\
\text { versus ALP } \\
\text { before }\end{array}$ & $\begin{array}{l}\text { Urea before } \\
\text { versus AST after }\end{array}$ & $\begin{array}{l}\text { Urea before } \\
\text { versus ALT after }\end{array}$ & $\begin{array}{l}\text { Urea after } \\
\text { versus ALP } \\
\text { before }\end{array}$ \\
\hline$r$ & -0.110 & -0.209 & -0.168 & -0.120 & -0.134 & -0.167 \\
\hline $\mathrm{p}$ Value & 0.457 & 0.154 & 0.252 & 0.418 & 0.363 & 0.256 \\
\hline
\end{tabular}

*Significant level at $p<0.05$; before, before exercise; after, after exercise; r, Pearson correlation coefficient. 
investigated the levels of liver enzymes in acute aerobic exercise in sedentary women and observed that AST and ALP levels increase significantly but there was no significant change in ALT enzyme levels. However, in our own study, a significant decrease $(\mathrm{p}<0.05)$ in ALT activities after a football exercise (figure 4) was observed. The possible explanation for this is sparse at this moment; however, this could possibly explain the critical metabolic activities the liver is involved in during exercise, which may possibly involve this enzyme, since ALT is largely found in the liver with much lower concentrations than in the skeletal muscles. Thus, based on tissue distribution, ALT seems to be one of the most specific markers of liver injury; ${ }^{14}$ thus, a significant decrease in ALT in this study could suggest that soccer as a form of exercise may not pose any danger to liver function. Moreover, our study further agreed with a similar study by Ghorbani and Gaeini ${ }^{15}$ that evaluated the effects of high-intensity training on liver enzyme levels in soccer players and observed a significant increase in plasma concentration of AST and ALP whereas there was no significant increase in plasma concentration of ALT. Increased activities in AST and ALP after soccer exercise could be a result of some leak from skeletal muscles as the enzymes are found to play some roles in ensuring the continual release of ATP during exercise activities as they catabolise amino acids that enter into the tricarboxylic acid (TCA) cycle. Also, ALP as a hydrolase ${ }^{16}$ contributes to the hydrolysis of metabolites such as fats across cell membranes to produce energy; hence, the increase in ALP activities after football activity could aid gluconeogenesis and lipid peroxidation during football activity. ${ }^{12}$ However, the findings in this study are at variance with the study of Bijeh $e t a l^{8}$ where AST and ALT levels after 8 weeks of swimming exercise in healthy women had no significant change. This could probably be due to the difference in the type of sporting activities evaluated in these studies, as football activity is more of an anaerobic type of exercise as compared with swimming that is primarily aerobic, and to the duration of the study.

\section{Degree of associations between renal and liver biochemical markers before and after football exercise}

Furthermore, we evaluated the degree of association among the parameters of the study using Pearson's correlation. It was observed that a positive but nonsignificant $(p>0.05)$ association existed between urea and creatinine (table 2). This observation thus suggests that urea and creatinine both follow the same trend but are primarily independent of each other despite the fact that they are both non-protein nitrogenous compounds. However, a positive and significant $(\mathrm{p}<0.05)$ correlation was observed among the liver enzymes (table 3), suggesting that these enzymes
Summary box

Regular football exercise is associated with increased urea creatinine, aspartate aminotransaminase (AST) and alkaline phosphatase.

- A decrease in alanine aminotransaminase (ALT) plasma level was observed among young men who play football regularly.

- There is a positive but non-significant relationship between creatinine and urea among footballers.

- A positive and significant relationship was observed between AST and ALT before football exercise.

- These observations should be kept in mind when interpreting biochemical parameters for renal and liver function among regular football players

possibly originate from similar sources, primarily the liver and the skeletal muscles; thus, stress as a result of exercise could possibly lead to leakage of some of these enzymes into the plasma in a similar fashion. However, an evaluation of the degree of association between the renal and liver function parameters (table 4 ) showed a negative but non-significant correlation $(p>0.05)$, thus suggesting that there is no clear-cut relationship between these parameters in this group of volunteers.

\section{Conclusion}

Sporting activities should be properly coordinated and regulated as the study has shown that sports bring about an increase in liver enzymes and renal parameters of an individual who participates regularly, and the significant changes in these biochemical parameters may be misleading as diseased condition in such individuals. Thus, caution should be observed in interpreting liver enzyme and renal function biochemical parameters among soccer players.

Acknowledgements Authors are grateful to all undergraduate students of the College of Medicine, University of Lagos, who participated in this study.

Contributors EOA conceptualised and designed the study. He also participated in the collection, analysis and interpretation of the data as well as the drafting and review of the manuscript. EFA, AOC and ONO all participated in data collection, analysis of the data and drafting of the manuscript. AFO and EOO participated in the analysis of the data, drafting and review of the manuscript.

Competing interests None declared.

Ethics approval IRB Lagos University Teaching Hospital, Lagos, Nigeria, ADM/DCST/HREC/126.

Provenance and peer review Not commissioned; externally peer reviewed.

Data sharing statement This study also evaluated the effects of regular sporting activity on male reproductive hormone parameters, which has been sent to one of our institutional journals for possible publication. All data from this study can be accessed and obtained through the corresponding author.

Open Access This is an Open Access article distributed in accordance with the Creative Commons Attribution Non Commercial (CC BY-NC 4.0) license, which permits others to distribute, remix, adapt, build upon this work noncommercially, and license their derivative works on different terms, provided the original work is properly cited and the use is non-commercial. See: http:// creativecommons.org/licenses/by-nc/4.0/ 
(C) Article author(s) (or their employer(s) unless otherwise stated in the text of the article) 2017. All rights reserved. No commercial use is permitted unless otherwise expressly granted.

\section{REFERENCES}

1. Zdrenghea D, Poantă L, Pop D, et al. Physical training-beyond increasing exercise capacity. Rom J Intern Med 2008;46:17-27.

2. Kawano M, Shono N, Yoshimura T, et al. Improved cardiorespiratory fitness correlates with changes in the number and size of small dense LDL: randomized controlled trial with exercise training and dietary instruction. Intern Med 2009;48:25-32.

3. De Matos MG, Calmeiro L, Da Fonseca D. Effect of physical activity on anxiety and depression. Presse Med 2009;8:8-12.

4. Malatesta D, Werlen C, Bulfaro S, et al. Effect of high-intensity interval exercise on lipid oxidation during postexercise recovery. Med Sci Sports Exerc 2009;41:364-74.

5. Jacobs DR, Sluik D, Rokling-Andersen $\mathrm{MH}$, et al. Association of 1-y changes in diet pattern with cardiovascular disease risk factors and adipokines: results from the 1-y randomized Oslo Diet and Exercise Study. Am J Clin Nutr 2009;89:509-17.

6. Weinberger M, Abu-Hasan M. Perceptions and pathophysiology of dyspnea and exercise intolerance. Pediatr Clin North Am 2009;56:33-48.

7. Ahmad $\mathrm{M}$, Aminai $\mathrm{M}$, Marefati $\mathrm{H}$. The impression of aerobic exercise to enzymes measure and liver fat in the man suffering to non- alcoholic fatty liver. International Research Journal of Applied and Basic Sciences (IRJABS) 2012;3:1897-901.

8. Bijeh $\mathrm{N}$, et al. Effects of 8 weeks swimming training on hepatic enzymes and hematological values in young females. Int I J Basic Sci Appl Res 2013;1:123-8.

9. Welsh RC, Warburton DER, Haykowsky MJ, et al. Hematological response to the half Ironman triathlon. Med Sci Sports Exerc 1999;31:S63.

10. Melamed I, Romem Y, Keren G, et al. March myoglobinemia: a hazard to renal function. Arch Intern Med 1982;142:1277-9.

11. MacSearraigh ET, Kallmeyer JC, Schiff HB. Acute renal failure in marathon runners. Nephron 1979;24:236-40.

12. Bürger-Mendonça $M$, Bielavsky $M$, Barbosa FC. Liver overload in Brazilian triathletes after half-Ironman competition is related muscle fatigue. Ann Hepatol 2008;7:245-8.

13. Yazgaldi $\mathrm{N}$, Abuzar $\mathrm{M}$, et al. Response of liver enzymes to acute aerobic exercise in sedentary human subjects. $N Y$ Sci J 2014;7:89-92.

14. Dufour Robert D. Liver diseases. In: edited by Burtis CA, Ashwood ER, David EB, Tietz textbook of clinical chemistry and molecular diagnostics, 2006;1777-847.

15. Ghorbani $P$, Gaeini A.A. The effect of one bout high intensity interval training on liver enzymes level in elite soccer players. J Basic Appl Sci 2013:5:1191-4.

16. Nayudu RV, de Meis L. Energy transduction at the catalytic site of enzymes: hydrolysis of phosphoester bonds and synthesis of pyrophosphate by alkaline phosphatase. FEBS Lett 1989;255: 163-6. 